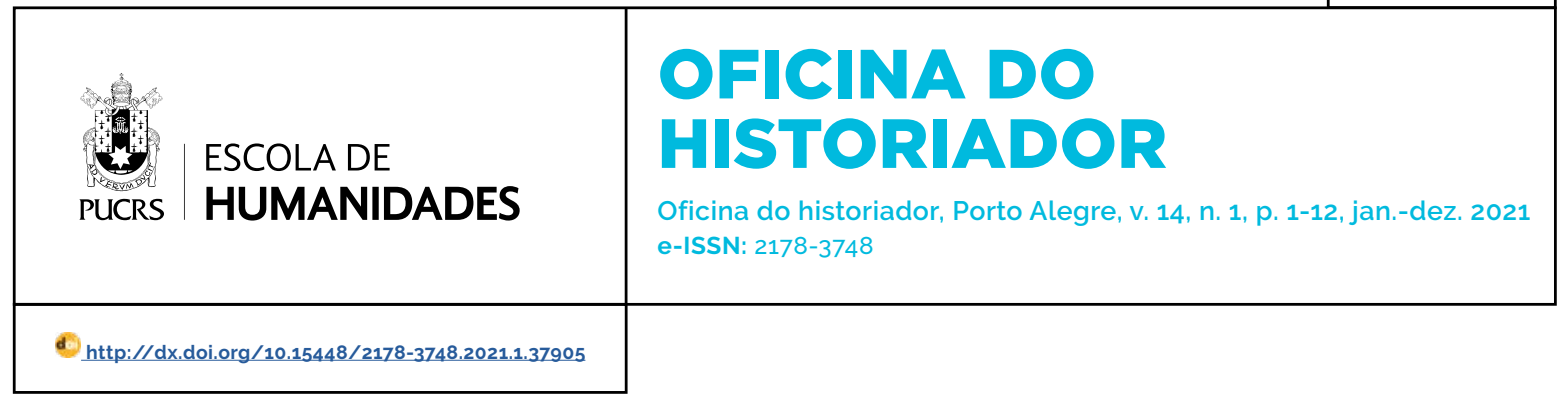

SEÇÃO: ARTIGOS

\title{
Processos de habilitações ao clero secular de Mariana (1745-1764)
}

Processes of qualification to the secular clergy of Mariana (1745-1764)

\author{
Josimar Faria Duarte ${ }^{1}$ \\ orcid.org/0000-0003-4986-3141 \\ josimarfaria@yahoo.com.br
}

Recebido em: 30/4/2020.

Aprovado em: 14/6/2020.

Publicado em: 13/4/2021.

\section{(c) (1)}

Artigo está licenciado sob forma de uma licença Creative Commons Atribuição 4.0 Internacional.
Resumo: O estudo em tela versa sobre os Processos de habilitação ao clero secular de Mariana, durante o governo episcopal de frei Manuel da Cruz (17451764). O instrumento de pesquisa consistiu no uso do método prosopográfico, proposto pela história regional. As fontes de sustentação empíricas utilizadas foram documentos manuscritos consultados no Arquivo Eclesiástico da Arquidiocese de Mariana (AEAM). O aparato teórico conceitual refere-se à recente historiografia sobre império, redes, conexões e relações entre centro e periferia, poder central e poder local. Os resultados dessa pesquisa são apresentados aqui a partir de narrativas modais.

Palavras-chave: Clero secular. Processos de habilitação. Diocese de Mariana.

Abstract: The study on screen deals with the qualification processes for the secular clergy de Mariana, during the episcopal government of frei Manuel da Cruz (1745-1764). The research instrument consisted of using the prosopographic method, proposed by regional history. The empirical sources of support used were handwritten documents consulted in the Ecclesiastical Archive of the Archdiocese of Mariana. The conceptual theoretical apparatus refers to the recent historiography on empire, networks, connections and relations between center and periphery, central power and local power. The results of this research are presented here from modal narratives.

Keywords: Secular clergy. Qualification processes. Diocese of Mariana.

\section{Introdução}

Em Mariana setecentista, como nas demais partes do império português, o clero secular era restrito aos sujeitos considerados "dignos e honrados" na ascendência, vida e costumes. Por isso, os aspirantes ao sacerdócio passavam por inquirições da "limpeza de sangue, vida e costumes e da limpeza de sangue dos seus pais", denominadas de Processos de Habilitação de Genere (VIDE, 1853, p. 244).

Pelas investigações de Genere, as autoridades eclesiásticas realizavam trabalhos sumários sobre as origens sociais dos futuros membros de seu corpus. Visavam, com isso, evitar "problemas de costumes" de padres que "passavam toda a sua vida como errantes e vagabundos em diversas cortes, ou mergulhados no cuidado dos negócios temporais, abandonando seu pastoreio e negligenciando o cuidado com as ovelhas". Para, assim, formar um clero que "apresenta no modo de vestir, na atitude, no andar, no falar e em toda outra coisa, nada que não seja grave, modesto e cheio de religião" (TRENTO, 1781, p. 215). Normas que 
foram afixadas nas Constituições Primeiras do Arcebispado da Bahia da forma seguinte:

\begin{abstract}
Mandamos que os que quiserem ser promovidos, assim a Ordens Menores, como Sacras, depois de examinados, e aprovados nos facão petição, declarando nela seu nome, e sobrenome, e os de seu pai, e mãe, e da terra d'onde são naturais, e onde residem, ou residiram considerável tempo; o qual será a nosso arbítrio. E na sua petição se lhe porá por despacho, que se parte carta de vita, et moribus, a qual, passada em seu nome, irá por nós assinada, ou por nosso Previsor; e nela se mandará ao Pároco ou do Ordenando, e aos mais Párocos do lugar, onde ele residir, ou tiver residido tempo considerável, que no primeiro Domingo, ou dia Santo á estação da Missa denunciem, como natural de tal Freguesia [...] e que se alguma pessoa souber dos impedimentos abaixo declarados, se the manda com pena de obediência, e de excomunhão maior o diga [...] (VIDE, 1853, p. 244).
\end{abstract}

Desse modo, teoricamente, excluiam-se do clero secular luso-brasileiro os sujeitos que possuíam elementos distintos da silhueta traçada pelo Concilio Ecumênico de Trento, como os candidatos que possuiam "nódoa" de "sangue" em sua ascendência (AZEVEDO, 1978, p. 326).

\section{Os Processos de Pureza de Sangue}

Como difundido pela historiografia, a institucionalização dos processos de "pureza de sangue" estava vinculada aos estatutos de Toledo, amplamente divulgados na península Ibérica após a expulsão dos judeus e mouros. Isso foi em torno de 1241, quando o rei Fernando III mandou traduzir para o castelhano às antigas leis do reino visigodo de Toledo, Lider Iudiciorum, que distinguia os livres e os escravos, com o intuito de marcar os libertos com o sinal de impureza de seu sangue e ascendência, para assim impedi-los de ter cônjuge entre as linhagens das familias que se definiam como nobres. No reino de Toledo, uma mulher tinha, assim, que comprovar a pureza de sangue para se casar com um cavaleiro. Ao restaurar e adotar esse estatuto, os reis buscavam "naturalizar" na península Ibérica a concepção "arbitrária" de que os conversos eram falsos cristãos. Essa ideia se assentava sobre a oposição entre dois grupos distintos, os cristãos velhos convictos e os novos, vistos como impuros de sangue. Isolavam-se, assim, os conversos e concediam-se privilégios aos ditos de sangue de cristãos velhos (OLIVAL, 2001, p. 151-182).

Posteriormente, em 1449, os estatutos de "limpeza de sangue" foram autorizados pelo papa João III, afastando de cargos e de ofícios públicos os descendentes de judeus, cristãos-novos, mouros, negros, mulatos e outras "infectas nações" (OLIVAL, 2001, p. 182). Em seguida, esse estatuto passou a ser adotado pelo sistema de recrutamento eclesiástico, promulgado em 25 de janeiro de 1588 pelo papa Xisto $V$, através da breve Dudum Charissimi in Christo. O referido estatuto proibia a ocupação nos serviços eclesiásticos por gerações de mestiços que apresentassem mesclas de sangue com judeus, cristãos-novos, árabes ou negros. Essas medidas foram aceitas sem reservas em Portugal e nos territórios de seu império, promulgadas em sínodo provincial do bispado de Funchal realizado em setembro de 1588 (PAIVA, 2011, p. 56).

No entanto, na prática, essas inquirições não eram impedimentos para admissão no sacerdócio aos que tinham comprovação de "nódoa" em sua genealogia. Essa servia apenas para construir a diferenciação entre os membros do clero na hora da admissão nas ordens sacras. Construindo, assim, um sistema de pedir, conceder ou receber. A dispensa dos impedimentos legalmente instaurados não eram ações isoladas ou distorções, mas atos que se inseriam em uma cadeia de obrigações de reciprocidades inerentes ao funcionamento daquela instituição, dentro de uma lógica típica de Antigo Regime.

Neste sentido, Anderson Oliveira (2008, p. 7-8) afirmou que "a dispensa do 'defeito de cor' deveria advir de uma 'graça' concedida pelo bispo que tinha autoridade para outorgar tal privilégio" pela qual a Igreja católica reiterava "a sua função de organismo perpetuador de uma ordem social desigual". Receber a "graça" da dispensa do defeito de sangue não era uma ação isolada, mas a reafirmação da existência de uma hierarquia interna que impunha relações de subordinação e submissão eclesiástica, notórias entre o clero "natural" e o de "cor". Era, assim, mais um dos princípios de diferenciação no corpo eclesiástico que dificultava o trânsito de pessoas no clero. Os 
homens de cor e os que se dedicavam aos ofícios manuais, ao ingressarem no sacerdócio, eram marcados como um segmento diferenciado do clero. As restrições impostas, portanto, ajudavam a fazer cumprir as diferenciações da ordem social estabelecida, ao tempo que envolvia vários indivíduos atraidos pelos beneficios, fossem materiais ou sociais, que o clero proporcionava.

Fazer parte do clero dava prestígio aos indivíduos e seus familiares. Funcionava como uma carta de apresentação das familias da época para resolver problemas com a purificação do sangue, solicitar cargos públicos ou de incorporação militar, até mesmo a compra de títulos de nobreza. Por isso era recorrente, entre as familias ricas, a estratégia de encaminhar um filho ao clero (PAIVA, 2012, p. 178).

Desse modo, a carreira eclesiástica era bastante atrativa, uma vez que possibilitava aos sacerdotes e seus familiares provarem para toda a sociedade a pureza de sua ascendência, afastando, oficialmente, qualquer suspeita de possuir o estigma do "sangue impuro". Tratava-se, portanto, de um problema religioso com forte impacto na estrutura social e política da época moderna que excluia, limitava e segregava os descendentes de judeus, escravos ou outra mistura que não partilhassem da nobreza (SEIDL, 2008, p. 21).

Os interessados na ordenação sacerdotal deveriam, portanto, submeter-se ao estatuto de "limpeza de sangue", comprovando não possuir parentescos com nações "infectas".

\section{Processos de Habilitação de Genere em Mariana}

Após o periodo de mais de um século, as definições de Toledo foram adaptadas às especificidades do território da América portuguesa, com a publicação das Constituições Primeiras do Arcebispado da Bahia que, além da mescla de sangue impuro, impunham obstáculos aos candidatos nascidos de uniões consensuais ou de casamentos desfeitos ou que possuissem "defeitos físicos", demências, mancebia ou vida dissoluta (VIDE, 1853, p. 187). Daí em diante, os prelados da América portuguesa passaram a ser admitidos após minucioso processo de investigação da "pureza de sangue", dos bons costumes e da fidelidade doutrinal:

\begin{abstract}
Se façam, como devem, as diligências (1) de vida e costumes aos Ordenados, e concorram neles às qualidades que o direito, e Concilio de Trento requerem, e sejam só admitidos a ordens aqueles de que se pôde esperar exemplo de vida, mandamos que os que, pois de examinados, e aprovados no fação petição, declarando nelas naturais, e onde residem, ou residirão os de seus pais, e mãe e de terra d'onde são nosso árbitro. E na sua petição se the porá por despacho, que se por nós assignado, e nela se mandará ao (2) Pároco da Ordenando, e aos mais Párocos do lugar, onde ele residir, ou tiver residido tempo considerável, que no primeiro Domingo, ou dia santo á estação da Missa denuncie, com N. natural de tal freguesia, ou nela residente, filho de $\mathrm{N}$. e N. se quer ordenar estas Ordens: e que se alguma pessoa souber de impedimentos (3) abaixo declarados, se the manda com pena de obediência, e de excomunhão maior o diga [...] (VIDE, 1853, p. 92-93).
\end{abstract}

De acordo com esse documento, datado de 12 de junho de 1707, os Processos de Habilitação de Genere deveriam ser requeridos em época de "prima tonsura"2 por candidatos que já tinham 14 anos de idade, completado o curso preparatório de seminário (seminário menor) e que mostrassem ter vocações ao estado eclesiástico. Respondidas essas obrigações iniciais, eles deveriam dirigir-se à câmara eclesiástica da diocese e, após comprovarem rendimento anual de 25 mil-réis, depositarem os benefícios para diligências de processos. Nessa ocasião, o tesoureiro-mor da mitra deveria entregar-lhes recibo, pois, caso a quantia depositada fosse maior que as despesas, os seminaristas poderiam solicitar reembolsos (VIDE, 1853).

Em seguida, os candidatos eram encaminhados ao escrivão da referida câmara, que deveriam registrar nos autos da petição as características físicas do habilitante (tom da pele, cabelo, olhos, formato do nariz, número de dentes e vestuário), a

\footnotetext{
Segundo José Pedro Paiva (2012, p. 168), a prima tonsura não era um sacramento, nem um grau da ordem, mas a afirmação da disposição do candidato. Assinalava, portanto, a passagem do estado laico ao clerical. "O tonsurado ficava que o clérigo e, por analogia, as monjas e freiras, que eram submetidas quando da tomada de hábito religioso a um simulacro de tonsura, ficavam equiparadas aos clérigos em matéria de isenção e imunidades canónicas, se bem que nunca tivessem".
} 
naturalidade e ofícios dos pais, dos avós paternos e maternos. Após isso, eram copiadas as certidões de batismo dos suplicantes e de seus ascendentes, as certidões de casamento dos pais e avós e, em alguns casos, as cartas de compatriotas (VIDE, 1853).

Como era de praxe, em Mariana, ao invés de procurarem a câmara eclesiástica da diocese para iniciarem os processos, os suplicantes delegavam as obrigações de realizar tais petições aos vigários-gerais da paróquia em que residiam. A eles, posteriormente, as autoridades eclesiásticas incumbiam as obrigações de coletarem informações sobre a naturalidade dos suplicantes com "pessoas fidedignas e desinteressadas", as interrogando sobre:

\section{1 - Se o habilitando é batizado, é crismado? \\ 3 - Se é legítimo, e Havido legítimo Matrimônio? \\ 12 - Se é bígamo, por qualquer espécie de [?] bigamia? \\ 22 - Se é frequente em se confessar ou co- mungar?3}

Satisfeitas essas questões iniciais, as testemunhas assinavam seus depoimentos e a inquirição seguia para a segunda fase, que correspondia aos processos de Vita Et Moribus. Nesse momento, a vigário-geral dos processos de Habilitação de Genere encaminhava ao bispo da diocese as petições. Após aprovação do teor da documentação, as declarações deveriam ser conferidas novamente com os párocos das freguesias em que residia o suplicante e seus parentes. Como exemplo, temos o seguinte trecho:

Mando ao Reverendo Vigário que este leia o edital em voz alta, inteligivel em um dia festivo, e depois de publicada, afixará no lugar de costume onde estará por três dias sucessivos para que chegue a notícia de todos e findos estes o tirará, e passará certidão nos custos da publicação e fixará como teor dos impedimentos. ${ }^{4}$

Recebidas as petições, os párocos deveriam afixar nas portas de suas igrejas editais, e anunciarem, durante a estação da missa do primeiro domingo do mês ou em dias Santos de guarda, os nomes dos candidatos ao sacerdócio, interrogando aos fregueses sobre a naturalidade dos suplicantes, o local de residência, a profissão, a legitimidade das condições familiares de seus genitores e progenitores, se eles, pais ou avós, foram hereges ou apostados de fé católica, se possuiam antecedentes criminais, de direito ou de fato, ou se foram condenados a penas públicase se tinham dividas públicas. Todas as suspeitas deveriam ser informadas verbalmente ou por escrito por pessoas honestas e católicas que soubessem

1 - se o referido habilitando é filho legitimo;

2 - se cometeu algum crime ou ação em sua vida que o torne inábil e indigno do Estado Eclesiástico;

3 - se deve a alguém restituição de honra ou promessa de casamento;

4 - se é constrangido a tomar ordens;

5 - se incorreu em alguma irregularidade. ${ }^{5}$

Daí em diante, os processos passavam para a averiguação do comportamento social do suplicante e de seus parentes, visando a admitir no clero somente pessoas que fossem aceitas pela comunidade, com pureza moral, sanguínea e até mesmo da aparência física. Para essa averiguação, usavam-se as seguintes perguntas:

4 - Se tem parte de negro, ou mulato até quarto grau?

6 - Se é Curvado, aleijão de perna, braço, ou dedo, e se tem outra deformidade, que cause [?], ou nojo a quem o ver?

7 - Se lhe falta a vista principalmente no olho esquerdo, ou se tem ferida em algum deles, que cause deformidade?

8 - Se é enfermo de lepra, gota [piral?] ou outra doença contagiosa?

23 - Se é natural deste Bispado, ou se nele se tem feito compatriota? ${ }^{6}$

\footnotetext{
3 MARIANA. Arquivo Eclesiástico da Arquidiocese de Mariana (AEAM). Processos de Habilitação de genere et moribus de Acassio Golçalves, 1757. Armário 1, pasta: 1, fls.3.

4 MARIANA. Arquivo Eclesiástico da Arquidiocese de Mariana (AEAM). Processos de Habilitação de genere et moribus de conego Jacinto Ferreira dos Santos, 1757, p. 3. Armário 2, Pasta: 56.

5 MARIANA. Arquivo Eclesiástico da Arquidiocese de Mariana (AEAM). Processos de Habilitação de genere et moribus de conego Jacinto Ferreira dos Santos, 1757. Armário 2, Pasta: 56, fls. 3.

6 MARIANA. Arquivo Eclesiástico da Arquidiocese de Mariana (AEAM). Processos de Habilitação de genere et moribus de conego Jacinto Ferreira dos Santos, 1757. Armário 2, Pasta: 56, fls. 3.
} 
Após essas questões, a averiguação era se o candidato ou seus familiares exerceram profissões mecânicas, especificamente, no trabalho rural. Os considerados aptos em nobreza passavam a ser investigados nos vícios, em especial, no consumo de vinho e na prática de jogos, como os jogos de bola, se frequentavam tavernas ou outros estabelecimentos de escândalos, se haviam cometido crimes contra a fé ou vias de fatos.

Durante os Processos de Habilitação de Genere de Francisco de Paula Meireles, natural da Vila do Tijuco, testemunhas honradas e desinteressadas declararam que ouviram dizer que o candidato tinha cometido "o pecado sexto" (sic), o que significava que o suplicante havia praticado a "fornicação" sem casamento. Segundo as virtudes clericais, o desejo sexual de um homem e de uma mulher sem o casamento era um pecado, sendo, portanto, um impedimento de bons costumes para admissão no clero. Por isso, "o habilitante não pode se ordenar nesse bispado". Porém, as denúncias de formicação no pecado sexto não se confirmaram por "falta de testemunhas". Isso, porque, algumas testemunhas que ouviram dizer acabaram morrendo de morte não natural no desenrolar dos processos. ${ }^{7}$

Por fim, vasculhava-se o comportamento dos suplicantes, seus pais e avós nas obrigações com a monarquia, se os candidatos, antes de ingressarem no seminário, cometeram crimes, se seus pais e avós eram condenados, se deviam impostos, se tinham dividas públicas ativas, se a residência da familia na cidade era frequentada por pessoas que conspiravam contra a monarquia ou envolvidos em escândalos de conspirações.

Caso houvesse denúncias, as autoridades eclesiásticas tinham que registrá-las por escrito e conferi-las com quatro testemunhas fidedignas e desinteressadas. Provavelmente, em espaços pequenos, como das freguesias da diocese de Mariana, onde quase todas as familias se conheciam, seria impossivel reunir testemunhas sem quaisquer ligações com os suplicantes. Assim, é provável que nas investigações as testemunhas não prestassem informações que prejudicassem os processos.

Como exemplo, podemos mencionar os processos de habilitação de Francisco de Paula Meireles. No desenrolar do mesmo, chegou ao conhecimento do reverendo inquiridor que ele havia cometido, além do pecado de fornicação, homicídio com arma de fogo contra Bento Ferreira da Silva, natural da vila de Ferreira, bispado do Porto e morador no arraial do Tijuco. Testemunhas de processos de habilitação declararam ouvir dizer que "Francisco de Paula Meireles era batizado e crismado", porém "filho de mulato" e que vivia escandalosamente o pecado sexto com várias senhoras na cidade. ${ }^{8}$ Apesar disso, por falta de testemunhas, o aljube não confirmou as acusações e a inquirição teve seu desfecho no modo seguinte:

\begin{abstract}
Pelo ver e conhecer Sabe que o habilitando não é aleijado nem Corcovado e que não tem defeito nenhum deformidade alguma em seu corpo que cause escândalo ou provoque a irrisão que não é astênico de maneira que ouvi o provoque o vomito e que não é viciado nem assombrado do demônio e mais imundície ate o decimo de um decimo que o habilitando não cometeu homicidio algum nem para ele concorreu [?] que não concorreu para algum aborto que não é bígamo renegado revoltoso concubina ou incontinente e mais não disse ate o decimo quinto. Ao decimo sexto disse que também não sabe nem the consta que o habilitando esteja que relado ou denunciado as justiça que não incorreu em pena vil nem infâmia pública por defeito algum em que incorre em que incorre e que não é rebelde em receber sacramento que não teve oficio nem tutoria que o obrigue a dar contas que se pretende ordenar por sua vontade que é natural desde bispado e mais não disse assignou (AEAM, 1975, armário 04 . pasta 604 , fl. $25 \mathrm{~V}-30 \mathrm{~V}){ }^{9}$
\end{abstract}

Em seguida, os processos eram devolvidos à administração diocesana para que a sentença fosse lavrada pelo juiz das justificações de Genere, isto é, o cônego mais velho da jurisdição eclesiástica. Naquela época o cargo era ocupado por

\footnotetext{
MARIANA. Arquivo Eclesiástico da Arquidiocese de Mariana (AEAM). Processos de Habilitação de genere et moribus Francisco de Paula Meireles, 1775. Armário 04; Pasta: 604, fl. 25V a 30V.

S MARIANA. Arquivo Eclesiástico da Arquidiocese de Mariana (AEAM). Processos de Habilitação de genere et moribus Francisco de Paula Meireles, 1775. Armário 04; Pasta: 604, fl. 25v a 30v.

9 MARIANA. Arquivo Eclesiástico da Arquidiocese de Mariana (AEAM). Processos de Habilitação de genere et moribus Francisco de Paula Meireles, 1775. Armário 04; Pasta: 604, fl. 25V a 30V.
} 
Antônio João da Rocha. Terminada essa etapa, os relatos eram entregues ao bispo que se reunia com o cabildo e decidia pela admissão ou não dos suplicantes. Os que tivessem os processos justificados estavam automaticamente aceitos no clero secular. Já os que apresentassem suspeitas ou thes fosse comprovada a "nódoa" do sangue poderiam ser admitidos no clero por meio de mercês de perdão. Nesse sentido, os cânones do direito eclesiástico orientavam aos bispos que só autorizassem a ordenação desses se o candidato fosse zeloso, instruido e de elevado nivel moral.

Dispõem que se ordenem somente aqueles sujeitos, que os Bispos julgarem úteis, e necessários á sua Igreja, e neste nosso Arcebispado São mais necessários Clérigos para Cura das Almas, Missionários Zelosos, e Confessores, do que Clérigos Extravagantes, ordenados somente a título de Patrimônio, sem outra ciência mais que para dizer Missa, os quase além de serem de pouca utilidade para Igreja, muitas vezes vivem tão esquecidos de sua obrigações, que chegam a ser afronta do seu estado e danar algum de primeira tonsura, ou de Ordens Maiores, não será admitido elas, sem mostrar primeiro no exame que tem estudo (VIDE, 1853, p. 87).

É notória a aparente posição superior dos bispos no sistema sacerdotal. Eles possuíam papéis preponderantes na admissão dos suplicantes. Por isso, pela vontade deles muitos nativos, com defeitos de cor, tornaram-se sacerdotes. Neste sentido, Anderson Oliveira afirmou que essa postura dos bispos eram uma estratégia catequética, visto que a ordenação de candidatos com defeito de cor cumpriria um papel importante na reprodução social da lgreja, permitindo que os valores devocionais católicos atingissem escravos, libertos e filhos de escravos (OLIVEIRA, 2014, p. 7).

O primeiro bispo de Mariana, Manuel da Cruz, porém, não tinha afeição às ordenações dos suplicantes que apresentassem restrições de sangue. moral ou patrimônio, como deixa transparecer em trecho de sua carta enviada ao cardeal da Mota, em 1751:

Somente promovo as sagradas ordens àqueles que, tanto pela cultura como pela conduta edificante, julgo recomendável para este tão grande ministério e aptos a acudir a necessidade das Igrejas. Somente promovo os mais dignos deste bispado, porque no bispado do Rio de Janeiro e, em outros, são promovidos as Sagradas Ordens mulatos e outras nações sem qualidade. O bispo do Rio de Janeiro faz isso sem precedência das diligências de sangue, como de costumes. A pureza de sangue consta claramente das inquirições na forma de direito sentenciadas nas relações da Bahia. Não em sede vacante, mas, presidindo o reverendo arcebispo dom Sebastião da Vide; os bons costumes [...] temos que buscar os defeitos ainda que antigos, e esquecidos por emendá-los e formarem deles um perpetuo litígio. ${ }^{10}$

Nesse documento, o bispo afirma que só admitia no sacerdócio os candidatos que demostravam bons costumes morais e fidelidade doutrinal. Esses requisitos eram investigados de acordo com o decreto do Arcebispado da Bahia para impedir a admissão dos recém-convertidos à fé católica, tais como negros, mulatos e índios. Luiz Carlos Villalta (2007, p. 38-39), porém, nos informa que essas medidas, em alguns momentos, foram afrouxadas pelo bispo de Mariana, que ordenou considerável parcela de "homens de cor".

Sabemos que a instituição das ordens sacras aos suplicantes que apresentavam restrições nas habilitações não era uma exclusividade da colônia, mas algo que acontecia com frequência em Portugal, como nos informa os estudos de João Rocha Nunes (2019). Segundo esse autor, as reformas dos governos eclesiásticos de dom Miguel de Távora e de dom José de Bragança adotaram rígidas medidas nos processos de habilitação, reprovando número considerável de cristãos-novos, mouros e homens de origem rural. Nessa situação, houve queda no número de padres para celebrar as cerimônias religiosas, forçando esses mesmos bispos a deixarem a postura rígida e aceitarem candidatos com ascendências dúbias, principalmente os de origem camponesa.

O mesmo ocorreu na América espanhola, como sinalizam os estudos de Nazzari Valpuesta Abajo (2008). Segundo a autora, esse clero era composto por um número grande de estrangeiros desprovidos de dignidades ao estado eclesiástico na Europa,

10 CRUZ, Dom Frei Manuel. Carta para o Cardeal da Mota, 1751. In: Copiador de cartas particulares do Senhor Dom Frei Manuel da Cruz, Bispo do Maranhão e Mariana (1739-1762). Transcrição de Aldo Luiz Leone. Brasília: Ed. Senado Federal, 2008. p. 21. 
e que, por isso, migraram para os vice-reinados hispânicos na busca do perdão dos "defeitos" moribus para, então, ingressarem no clero. As várias restrições impostas teriam feito com que, neste lado do Atlântico, houvesse uma massa de clérigos despreparados para o exercício dos ofícios paroquiais. Em parte, isso se deu por causa das dificuldades no acesso aos livros e à formação de seminário na América, em geral, por causa da pobreza dos suplicantes, por serem de origem camponesa.

Além de limitarem a formação dos seminaristas, as origens pobres eram empecilho para admissão no clero na última fase das habilitações, processos denominados de patrimônio. Nesse, as familias dos suplicantes deveriam transferir parte de seus bens para a propriedade da diocese na forma de doações de terras, títulos, ações ou imóveis. Segundo o livro das Constituições Primeiras do Arcebispado da Bahia, esses processos se justificavam para evitar os "extravagantes, ordenados somente a título de Patrimônio, sem outra ciência mais que dizer Missa" (VIDE, 1853, p. 87). Os suplicantes que não tinham condições de arcar com esse último processo eram encaminhados ao ministério sacerdotal In nomine Christi nas ordens de São Francisco de Assis (franciscano) ou São Francisco de Paula (mínimos).

Por normas, todos esses processos eram lançados em pequenos cadernos, cujos fólios eram autenticados por assinaturas e selos diocesanos. Eles são importantes fontes nas pesquisas que buscam traçar o perfil e a inserção social do clero secular na América portuguesa, tais como a naturalidade, o local de residência, a profissão, a legitimidade de condições econômicas, os pais, os avós paternos e maternos. Neles, há anúncios do dia, local, bispo, dos examinadores responsáveis pelo processo de admissão do suplicante e os nomes dos escrivães encarregados pelos registros escritos. Também permite verificar os nomes dos suplicantes que foram promovidos ou reprovados em primeira tonsura e ordens menores até, finalmente, ao sacerdócio presbiteral. Sendo assim, neles arrolam informações prosopográficas que permitem estudar as histórias de vida dos clérigos coloniais e como elas se entrecruzavam com as hierarquias e as gradações simbólicas do período colonial.

Na historiografia, já é bem conhecido o valor heurístico dos processos de habilitação de Genere para a reconstrução da história social e da Igreja católica. Eles "informam sobre a formação e antecedentes, mas sem qualquer preocupação com os problemas do cotidiano nem com as relações entre os curas e os paroquianos" (NEVES, 1997, p. 19).

Além disso, essas ações de ascendência, vida e costumes, como ajuíza José Pedro Paiva (2012, p. 172), eram usadas para comprovação da pureza de sangue não só dos candidatos ao clero, mas de seus familiares na solicitação de cargos públicos, oficios e honrarias, o que "[...] constituía um mecanismo privilegiado de promoção social, quer através do mérito pessoal, quer por força de influências de tipo familiar e clientelar". Por isso, era praticamente impossivel a Igreja selecionar testemunhas sem laços de sangue ou interesses nos resultados dos processos de habilitação ao clero, o que possibilitava que se acobertassem informações que poderiam prejudicar as forças dos interesses envolvidos. Isso fazia com que esses processos nem sempre fossem muito rigorosos. Há claras evidências de ligações de redes, criadas em situações de ampla censura da Igreja, às origens sociais e à ocupação das famílias dos que seriam seus futuros clérigos. Portanto, são importantes fontes para os estudos de redes sociais.

As redes sociais são resultado das articulações e das interações entre individuos ou instituições que se ligam a fim de alcançar um objetivo comum. "As redes são percebidas como networks de relacionamentos, constituidos a partir das ações e das relações vivenciadas entre diversos individuos com acesso a informações e recursos diferenciados entre si" (FRAGOSO, 2010, p. 23). Pelas redes, os indivíduos compartilham afinidades, interesses e valores em relações de apoio mútuo como parentesco, amizade ou vizinhança. São associações que estão em constante movimento com fluxo de informações que aproximam e conectam pessoas distantes. "Essas diferenças potencializavam a possibilidade de sua imbricação, tirando-se assim partido das 
fraturas que cotidianamente eram identificadas nos diversos cenários sociais que compunham o império português" (FRAGOSO, 2010, p. 23).

No decorrer dos processos de ascendência, vida e costumes de habilitação ao clero secular, percebemos as tramas de interesses dos envolvidos no decorrer das inquirições, que tinham início pela indicação, na câmara eclesiástica, do nome do habilitando pelo pároco em petição que, em geral, seria posteriormente padrinho do suplicante indicado no ritual das ordens sacras. Seguiam, no rol de testemunhas selecionadas pelos párocos, que, em muitos casos, devido à pequena extensão das dioceses, não dispunham de pessoas desinteressadas, sem ligações de sangue ou amizade com os suplicantes. Isso contribuía para os "nódulos" de sangue, longínquos ou indiretos, fossem acobertadas pelas testemunhas.

Em muitos casos, elas admitiam ter ligações de parentesco com os suplicantes, mencionando, ainda, seus interesses na ordenação do parente, como receber empréstimos concedidos ao candidato para custear os estudos no seminário. Como é o caso, por exemplo, de João da Costa Ferreira e Araújo. No rol de testemunhas de seu processo de habilitação de Genere encontra-se listada sua irmã, Maria da Costa Ferreira, que, quando interrogada, afirmou que seu irmão era "batizado e que não é foi herege nem afastado da nossa Santa Fé Católica que não tem parte alguma de nação infecta e que não é descendente de pessoa herege ou novamente convertido". Também declarou que o irmão era digno dos graus do ministério, mesmo "tendo dividas públicas" com seu esposo a quem havia se comprometido pagar "quando terminasse os estudos no seminário".11 Assim como esse processo, muitos outros revelam as redes de crédito e endividamento dos candidatos à habilitação ao clero. Desse modo, portanto, os dados desses processos acabam por nos oferecer pistas para a análise e avaliação da dimensão das redes de sociabilidades dos sujeitos considerados "dignos e honrados" ao clero.
Outra questão a se considerar é a relação de interdependência dos candidatos com os membros do clero local. Pois, como sabemos, para a admissão era necessária a carta de pároco e do reitor do seminário, contendo o resultado de sua investigação sobre o perfil moral do suplicante, tais como dados biográficos e atestando da vontade do exercício do sacerdote. Ao redigir as cartas de recomendações, os párocos locais afirmavam que os candidatos indicados eram assíduos nas missas da paróquia, frequentavam nela os sacramentos, manifestavam gosto em ajudarem durante os atos religiosos, que eram obedientes nas ordens recebidas, que não frequentavam lugares profanos, que demostravam gosto pela leitura, faziam jejum, e se nunca se ausentavam do seminário por mais de três dias. Muitas vezes, também eram os párocos responsáveis por nomear as testemunhas e as instruir sobre o que deveriam declarar nos processos arrolados pela câmara eclesiástica.

A influência do clero local na admissão de suplicantes pode ser averiguada no desenrolar do processo de habilitação de Acácio Gonçalves Pereira. Esse teve início em 11 de janeiro de 1757:

Diz Acácio Gonçalves batizado na matriz de Nossa Senhora do Pillar das Congonhas do Sabará, filho legitimo de Antônio Gonçalves Pereira, natural da freguesia de Paiol de Mezlim do Couto da Ribeira, Arcebispado de Braga e de Josefa Cecilio da Encarnação, natural da freguesia de N. S. da Encarnação de Passe, recôncavo da cidade da Benta Neto pela parte Paterna de Domingos Gonçalves, da freguesia de Santa Maria de Palmeira Arcebispado de Braga, ou de Santa Maria de Adaufe vizinha da mesma freguesia e de sua mãe Izabel Perira da mesma freguesia de Palmeira, e pela parte Materna neto de João Baptista da Santa da freguesia de nossa S. da Encarnação de Passê, e de sua mãe Joanna Pera Maciel da freguesia de N. S. do Socorro Recôncavo da mesma cidade da Bahia, que ele se acha seguindo os estudos na cidade de Braga, há seis anos, já no segundo ano de Teologia, que ele deseja servir a Deus no estado sacerdotal, porém para conseguir the é necessário ser primeiro admitido por $V$. Ex ${ }^{a}$ Reverenda lhe faça as mesmas esmolas de admitir o suplicante para o estrado que pretende pra lhe passarem as ordens necessárias. Mostrando origens de limpeza de seu sangue. ${ }^{12}$

11 MARIANA. Arquivo Eclesiástico da Arquidiocese de Mariana (AEAM). Processos de Habilitação de genere et moribus João da Costa Ferreira e Araújo, 1750, p. Armário 04; Pasta 3, fls 12.

12 MARIANA. Arquivo Eclesiástico da Arquidiocese de Mariana (AEAM). Processos de Habilitação de genere et moribus de Acácio Gonçalves Pereira, 1757. Armário 01 - Pasta 0001, fls. 1, verso. 
O suplicante afirma que era natural de Minas Gerais, da freguesia de Congonhas do Sabará, filho legitimo de pai português e mãe natural das Minas Gerais, e que por seis anos estava cursando Teologia no seminário da cidade de Braga, em Portugal. Para obter a habilitação ao clero o candidato faz uma súplica de esmola, enquanto certeza de antecipação de uma dádiva. Paradoxalmente, a súplica demostrava a limitação e a dominação das vontades do suplicante, que em seu caráter humano reconhecia perante as figuras superioras do sistema sacerdotal que tudo que se acumulou não foi por valores, gosto ou conquista, mas, por dádiva gratuita, entregue pelas mãos do bispo.

Pela súplica iniciava-se o comprometimento no pacto social que costurava as relações sociais no clero de Mariana. Segundo Michel Foucault (2004) esse era composto por regras sociais minimas, ou migalhas de peso, que cambiavam o sistema de controle. Era o espaço que possibilitava a Igreja de Mariana conhecer o indivíduo suplicante, mediante a observação, classificação, seleção e catalogação do seu comportamento, para, assim, diferenciá-lo dos laicismos.

Depois da súplica, o juiz das justificações "de Genere" guardou o silêncio e seguiu o processo com a abertura da carta do vigário da Igreja de Congonhas de Sabará:

Aos sete dias do mês de maio de 1757 nesta cidade de Mariana em casa de pousada do reverendo escrivão da câmara e sendo aí por parte do recôncavo da Bahia das Congonhas de Sabará me foi remetido, mandado com assinado do pároco Antônio Monteiro de Noronha, carta fechada a qual abri e junto a esses autos de quem para constar este termo de ajuntamento eu a escrevi no auto dos processos da câmara episcopal. ${ }^{13}$

A carta, a qual se refere o fragmento, faz referência à trajetória do seminarista em Braga, informando que os pais do suplicante tinham origens na nobreza e que "possui limpeza de sangue, sem raça de Judeu, Mouro, Mourisco, Mulato, Herege ou outra infecta nação reprovada contra a nossa Santa fé Católica", como havia o pároco informando com oito testemunhas de qualidade em inquirições secretas "a portas fechadas". Nota-se que para adiantar a habilitação do suplicante, o vigário de Congonhas de Sabará fez as inquisições anteriores à juntada de abertura do processo e enviou os resultados em carta fechada, assim, como indicou a lista das testemunhas que recomendou para serem ouvidas pelo promotor da câmara eclesiástica:

Em execução das ordens de M. R.de Senhor dr. Promotor deste Bispado, são estas as testemunhas que achei legitimas para serem ouvidas:

1. Capitão Mor Antônio Dias Silva.

2. Capitão Mor Antônio Ribeiro do Campo.

3. Dona Joana Borges da Cunha

4. Doutor Gonçalves de Mello

5. Mello de Couto Souza

6. Alferes Mor Valério de Souza.

7. Capitão Geraldo Francisco da Luz

8. Capitão Antônio Francisco Bolina

Todos moradores neste bispado de Mariana. Todos juram dar ao doutor o conhecimento da verdade e apresentar nas cartas que the enviei. As testemunhas $3^{\mathrm{a}}$. E $4^{\mathrm{a}}$. conhecem melhor que todas o dito habilitando porque são moradores nesta freguesia, todos que informar ao senhor doutor promotor para deferir como for justa o que juro em verbo. ${ }^{14}$

É interessante observarmos que o vigário elegeu apenas duas testemunhas da freguesia de Congonhas de Sabará, doutor Gonçalves e dona Joana Borges da Cunha. Outra questão a se observar é a titulação dos informantes, quase todos possuiam patentes militares, ou seja, trata-se de pessoas de visivel respeito na sociedade da época. Já em relação ao gênero, nota-se que somente uma mulher foi escolhida por testemunha.

A inquirição das testemunhas teve início em 26 de setembro de 1757, com a declaração do capitão-mor Antônio Dias Silva. Solteiro, natural da freguesia de São Cristóvão da Vila do Var, Bispado do Porto, morador na cidade de Mariana "pouco mais ou menos de quarenta anos que vive nesta

\footnotetext{
13 MARIANA. Arquivo Eclesiástico da Arquidiocese de Mariana (AEAM). Processos de Habilitação de genere et moribus de Acácio Gonçalves Pereira, 1757. Armário 01 - Pasta 0001, fls. 1, verso.

14 MARIANA. Arquivo Eclesiástico da Arquidiocese de Mariana (AEAM). Processos de Habilitação de genere et moribus de Acácio Gonçalves Pereira, 1757. Armário 01 - Pasta 0001, fls. 1, verso.
} 
cidade", disse que conhecia muito bem o habilitando e sabia de sua naturalidade na freguesia de Congonhas de Sabará e que era morador em Portugal desde menino, para onde foi estudar no seminário. Disse que conhecia os pais e avós paternos do habilitando. Eram moradores em freguesias vizinhas no norte de Portugal e que tinha notícias que os pais moravam na freguesia de Congonhas do Sabará, onde viviam do trabatho agricola. Disse que teve notícias que os pais tinham 14 filhos: duas filhas foram para o convento português das carmelitas e que o filho mais velho morava em Braga desde menino, estudando no seminário. Por isso, nunca havia exercido trabalho mecânico nos campos das Minas Gerais. Aqui estão destacados dois elementos importantes do processo de formação sacerdotal. Tratava-se de um projeto de familia. Ao enviar um dos filhos para o seminário buscava-se solucionar problemas com o stuatus sociais. No exemplo em tela, o estigma da origem camponesa. ${ }^{15}$

A segunda testemunha, o capitão-mor Antônio Ribeiro, declarou ser casado e morador na cidade de Mariana há oito anos. Disse que conhecia os pais do habilitando, Antônio Gonçalves Pereira e Josefa Cecilia da Encarnação, desde que eram moradores no Arcebispado de Braga, onde viviam do trabalho em fazenda, porém, com a seca naquela freguesia vieram com os filhos para Minas Gerais, deixando o filho em Portugal para estudo em seminário. ${ }^{16}$ Percebe-se aqui uma contradição entre as testemunhas, a primeira afirma que o habilitando era natural das Minas e que foi enviado para Portugal. Já a segunda, que ele ficou em Braga quando os familiares vieram para as Minas Gerais, fugindo da seca nas terras de suas fazendas.

A terceira testemunha, dona Joana Borges da Cunha, viúva do capitão-mor José Borges da Cunha, afirmou que era vizinha do casal na freguesia de Congonhas do Sabará. Declarou que não conhecia o passado dos vizinhos. Mas, que o vigário tinha lhe dito que a mãe era natural do recôncavo da Bahia e que o pai era português. Ainda ouviu dizer na freguesia que o pai era viúvo e tinha deixado filhos em Portugal, mas, que o vigário a havia informado ser mentira. Por fim, declarou que não tinha certeza se o suplicante era pessoa digna, porque ainda não havia chegado à Vila de Sabará. No entanto, o pároco a havia instruido a dizer que conhecia muito bem o dito habilitante e que conhecia sua mãe, "Joanna Pereira Maciel e Avos materno" o que não era verdade "pois eles vivem na freguesia onde não são muito conhecidos". O relato deixa transparecer a influência que o clero local tinha na escolha das testemunhas, instruindo-as no que dizer ao juiz eclesiástico. Em alguns casos, percebe-se a contradição entre as testemunhas, que se apropriaram das informações de modo diferenciado.

A quarta testemunha era Gonçalves Mello, capelão da lgreja do Pilar de Congonhas do Sabará há 18 anos. Afirmou conhecer o habilitando desde que chegou àquela freguesia. Que era pessoa digna, assidua à missa e que demostrava gosto à leitura e aos atos religiosos. Fez algumas investigações do passado do habilitando junto a seus conhecidos no seminário de Braga, que atestaram que o candidato era filho de casamento legítimo, não tinha ascendência em nações infectas e que tinha fazia longos jejuns e que praticava a penitência. ${ }^{17}$

As demais testemunhas declararam que não sabiam, nem tinham ouvido dizer que o habilitante possuía alguma "mancha" de sangue em seu passado:

\footnotetext{
Ao quinto disse que sabe que/ o dito habilitando é filho legitimo dos ditos Pais e neto dos sobreditos Avos e que por filho e neto das ditas pessoas é tido havido tratado e comumente Reputado de todos sem que haja fama/ ou Rumor em contrario. Ao sexto disse não é parente ou aderente inimigo ou particular amigo de alguma das/ sobreditas pessoas. Ao sétimo disse que o habilitando seus [deteriorado] Avos maternos todos e a da[deteriorado] si foram e/ [deteriorado]. A oitava disse que não sabia nem tinha ouvido dizer de coisa alguma das so-
}

\footnotetext{
15 MARIANA. Arquivo Eclesiástico da Arquidiocese de Mariana (AEAM). Processos de Habilitação de genere et moribus de Acácio Gonçalves Pereira, 1757. Armário 01 - Pasta 0001, fls. 1, verso.

16 MARIANA. Arquivo Eclesiástico da Arquidiocese de Mariana (AEAM). Processos de Habilitação de genere et moribus de Acácio Gonçalves Pereira, 1757. Armário 01 - Pasta 0001, fls. 1, verso.

17 MARIANA. Arquivo Eclesiástico da Arquidiocese de Mariana (AEAM). Processos de Habilitação de genere et moribus de Acácio Gonçalves Pereira, 1757. Armário 01 - Pasta 0001, fls. 1, verso.
} 
breditas pessoas incorressem infâmia alguma onde foi dito de direito nem que cometessem heresia ou fosse penitencia do pelo santo oficio. Ao nono disse que tudo aquele tem dito e testemunha do é publico [?] e que por plena das sobreditas pessoas e pelas razões que dito tem e mais não disse e assignou. ${ }^{18}$

É preciso considerar na inquirição dessas testemunhas a proximidade entre os futuros presbiteros e o pároco, que organizava as inquirições, instruindo as testemunhas no que deveriam falar ao juiz eclesiástico dos de Genere. Notam-se, também, contradições nas informações, porém, todas elas atestavam o que a Igreja procurava saber: se o candidato possuía limpeza de sangue, boa indole moral e se não exercitou trabalho mecânico, como o camponês. Com isso, a Igreja queria assegurar-se que estavam ingressando ao clero pessoas fidedignas na doutrina, afastando-se o receio de serem admitidos traidores ou outros candidatos que iriam gerar problemas que atingiriam a todo o corpo eclesial. Por tanto, a admissão desse suplicante condizia com um perfil almejado pela Igreja pós-Trento.

\section{Considerações finas}

Pelo que foi exposto ao longo artigo, podemos afirmar que a diocese de Mariana se formou um corpo profissional de homens, que na sua maioria, eram brancos e de origem na elite local. Mas, contrariando aos ditames impostos pelos cânones do Arcebispado da Bahia, houve espaço para as ordenações de sacerdotes com origem nas familias camponesas, carentes do ponto de vista intelectual e econômico. Também houve espaço para uma pequena parcela de homens de cor, fossem esses pardos ou indígenas. No entanto, resguardando-se as virtudes morais do concílio de Trento.

Em uma análise parcial, podemos dizer que na diocese de Mariana os processos de inquirições de ascendência, vida e costumes dos sujeitos considerados não serviam como restrição aos sujeitos com comprovação de "nódoa" em sua genealogia ao sacerdócio. Neste sentido, os dados aferidos em nossa pesquisa demostram que no periodo de 1749-1762 foram registrados 231 processos de habilitações de Genere. Sobre as origens dos habilitantes, constam que 104 eram do reino, um do Maranhão, três da Paraíba, um de Pernambuco, dois da Bahia, oito do Rio de Janeiro, 10 de São Paulo, 102 de Minas Gerais e um não identificado. Dos que vieram de Portugal, 42 apresentavam restrições de sangue, um na moral, três físicas, 21 intelectuais e cinco patrimoniais. Entre os naturais da diocese, 29 apresentavam problemas de sangue ou físico. Os demais, naturais de outras partes da colônia, 31 apresentavam problemas de sangue. Apesar disso, apenas três dos suplicantes foram considerados inaptos ao sacerdócio por causa de defeitos físicos.

Desse modo, portanto, podemos concluir que as habilitações de Genere serviam como forma de ritualização, isto é, mais uma das alternativas de mostrar as diferenciações entre os membros do clero colonial, a partir de uma hierarquia baseada na limpeza de sangue. Tudo isso, para a construção e a afirmação de um sistema típico do Antigo Regime, baseado em pedir, conceder ou receber.

\section{Referencias}

VIDE, Dom Sebastião Monteiro da. Constituições Primeiras do Arcebispado da Bahia. (Impressas em Lisboa no ano de 1719, e em Coimbra em 1720). São Paulo: Tip. 2 de Dezembro, 1853.

ABAJO, Nazario Valpuesta. El clero secular en la América hispana del siglo XVI. Cidade de edição: Biblioteca de Autores, 2008.

FOUCAULT, Michel. Vigiar e punir: a história das violências nas prisões. Petrópolis: Vozes, 2004.

FRAGOSO, João; GOUVÊA, Maria de Fátima. Introdução. In: FRAGOSO, João; GOUVÊA, Maria de Fátima (org.). Na trama das redes: política e negócios no império português, séculos XVI-XVIII. Rio de Janeiro: Civilização Brasileira, 2010.

NEVES, Guilherme Pereira das. E receberá mercê: a Mesa de Consciência e Ordens e o clero secular no Brasil (1808-1828). Rio de Janeiro: Arquivo Nacional, 1997.

NUNES, João Rocha. A reforma católica na diocese de Viseu (1552-1639). Completar ref. Coimbra: Faculdade de Letras da Universidade de Coimbra, 2010.

OLIVAL, Fernanda. As ordens militares e o Estado moderno; honra, mercê e venalidade em Portugal (16411789). Lisboa: Estar, 2001

18 MARIANA. Arquivo Eclesiástico da Arquidiocese de Mariana (AEAM). Processos de Habilitação de genere et moribus de Acácio Gonçalves Pereira, 1757. Armário 01 - Pasta 0001, fls. 1, verso. 
OLIVEIRA, Anderson José Machado de. Suplicando a "dispensa do defeito da cor": clero secular e estratégias de mobilidade social no Bispado do Rio de Janeiro século XVIII. In: ENCONTRO DE HISTÓRIA ANPUH-RJ. 2008. Disponivel em: http://encontro2008.ri.anpuh. org/resources/content/anais/1212773302_ARQUIVO_Texto-AndersondeOliveira-Anpuh-RJ-2008.pdf. Acesso em: 03 fev. 2018.

OLIVEIRA, Anderson José Machado de. Trajetórias de clérigos de cor na América Portuguesa: catolicismo, hierarquias e mobilidade social. Andes, Salta, v. 25, 2014.

PAIVA, José Pedro. Um corpo entre outros corpos sociais: o clero. Revista de História das Ideias, [S. L.], v. 33. n. 166, 2012. https://doi.org/10.14195/2183-8925_33_8.

PAIVA, José Pedro. Baluartes da fé e da disciplina: o enlace entre a Inquisição e os bispos em Portugal (15361750). Coimbra: Editora da Universidade de Coimbra, 2011. https://doi.org/10.14195/978-989-26-0217-2.

SEIDL, Ernesto. Entrando no mundo da igreja: o estudo das elites eclesiásticas. In: CORADINI, Odaci Luiz (org.). Estudos de grupos dirigentes no Rio Grande do Sul: algumas considerações recentes. Porto Alegre: Editora da UFRGS, 2008.

VILLALTA, Luiz Carlos. A Igreja, a sociedade e o clero. In: LAGE, Maria Efigênia de Resende; VILLALTA, Luiz Carlos (org.). História de Minas Gerais: as Minas setecentistas 2. Belo Horizonte: Autêntica; Companhia do Tempo, 2007.

\section{Josimar Faria Duarte}

Doutor em História Social pela Universidade Federal do Rio de Janeiro (UFRJ), no Rio de Janeiro, RJ, Brasil.

\section{Endereço para correspondência}

Josimar Faria Duarte

Av. Pedro Calmon, 550

Cidade Universitária, 21941901

Rio de Janeiro, RJ, Brasil 